\title{
Trump, the Democrats, and the Polarisation of Immigration Politics
}

\author{
Dr Richard Johnson (Lecturer in US Politics, Lancaster University)
}

Scholars have argued that American politics has undergone 'asymmetric polarisation', whereby Republican Party elites have become more conservative, but Democratic Party elites have stayed roughly in the same ideological place in the past two decades (e.g., Mann \& Ornstein 2012, Theriault 2013, Grossman \& Hopkins 2015, Hacker \& Pierson 2015). In this article, immigration policy is considered under this light. The article proposes that the politics of immigration control defies the asymmetric polarisation thesis. While Republican elites have become much more supportive of restrictive immigration policies, Democratic Party elites have shifted to support far more permissive immigration policies than in the recent past. The article then assesses the electoral implications of the parties' stances.

\section{Republican Presidents and Immigration Policy}

Donald Trump's immigration policies -- such as a ban on immigration from Muslim-majority countries, separation of families who cross the border illegally, removing protected status from those brought to the United States illegally as children, increased denial of asylum seeker claims, and opposition to a variety of visa programmes - represent a major shift in Republican Party policy at the presidential level.

Earlier Republican presidents tended to support permissive immigration policies, which they viewed as positive for business. In the 1980 presidential election, Ronald Reagan asked, 'rather than putting up a fence, why don't we...make it possible for them to come here legally with a work permit and, then, while they're working here and earning here, they pay taxes here. And when they want to go back, they can go back. Open the border both ways'. As president, Reagan signed one of the most generous amnesty laws in US history, providing legal status to all illegal immigrants who lacked a criminal record and had been in the United States for at least four years before the bill's passage.

Reagan's successor, George H W Bush, continued this expansionary approach. In 1990, he signed a law which increased net immigration numbers into the United States to as many as 700,000 per year. Bush praised, 'we open the front door to increased legal immigration...Immigration is not just a link to America's past; it's also a bridge to America's future'. In 2007, his son George W Bush attempted to pass a bill which would have provided legal status for up to 12 million illegal immigrants.

Some policies supported by past Republican presidents have been directly condemned by President Trump. George H W Bush's 1990 Immigration Act expanded visas available for family members, workers, and those from countries with low admittance to the United States. The last innovation, known as the 'Diversity Immigrant Visa', has drawn particular ire of President Trump. He told graduates of the FBI academy,

'They have a lottery. You pick people. You think the countries are giving us their best people? No. What kind of a system is that? They give us their worst people, they put them in a bin. But in his hand when he's picking these people, it's really the worst of the worst. Congratulations, you're going to the United States. What a system.'

It would be wrong, however, to think that the Republican Party's shift on immigration policy has been driven by Donald Trump alone. Trump's stance on immigration reflects existing conviction among Republican voters. While some commentators believe that voters change their views on policy issues to match those of their preferred candidate (Lenz 2012, Tesler 2015), Republican voters have expressed support for strongly pro-border policies before Trump's candidacy. According to a 2014 survey by the Chicago Council on Global Affairs, $86 \%$ of self-identified Republican voters considered immigration control to be 'somewhat' or 'very' important, and $73 \%$ believed that immigrants and refugees were a 'threat'. A FOX News poll from July 2015, a year before Trump won the nomination, asked Republicans 
what they thought about Trump's comments that Mexico sends rapists, crime, and drugs over the US border. $70 \%$ of Republicans thought that Trump was 'basically right'.

As John Sides and colleagues have recently suggested, Trump was much better aligned with the Republican primary electorate than any of the other 16 Republican candidates (Sides et al 2018). The electorate already had polarised on immigration before Trump's arrival.

Trump's presidency has encouraged party elites to reflect the party electorate. In June $2018,82 \%$ of Republican House members voted to reduce the levels of legal migration by 40 percent, the largest reduction since the infamous Immigration Act of 1924, which introduced national-origin quotas aimed at limiting the numbers of southern and eastern Europeans entering the United States. In 1996, when Congress last considered reducing legal migration, three-quarters of Senate Republicans - including Mitch McConnell and Orrin Hatch - voted not to reduce numbers.

\section{Policy Change in the Democratic Party}

The Republican Party's increasing conservatism on immigration has received a good deal of attention, but less discussion has focused on Democrats' shifting attitudes. Only one or two decades ago, leading Democrats expressed scepticism about immigration in ways which would shock many American liberals today.

In the 1990s, Democrats agreed that illegal immigration was harmful. Bill Clinton's message in his 1995 State of the Union Address would be unthinkable from a mainstream Democratic politician today:

'All Americans, not only in the states most heavily affected but in every place in this country, are rightly disturbed by the large numbers of illegal aliens entering our country. The jobs they hold might otherwise be held by citizens or legal immigrants. The public service they use impose burdens on our taxpayers. That's why our administration has moved aggressively to secure our borders more by hiring a record number of new border guards, by deporting twice as many criminal aliens as ever before, by cracking down on illegal hiring, by barring welfare benefits to illegal aliens.'

The following year, Clinton signed the Illegal Immigration Reform and Immigrant Responsibility Act. The Act made it much easier for federal agents to deport illegal immigrants. Before the 1996 law, illegal immigrants were deported only if they were convicted of a serious crime involving more than five years in prison. The act made even minor offences subject to immediate deportation. Clinton's Act also contained provisions staunchly opposed by Democrats today, such as authorisation for building a border wall and the restriction of illegal immigrants from receiving services such as subsidised public university education. It contained provisions which made it impossible for illegal immigrants to apply for legal status even if they married a US citizen, without first spending ten years outside of the United States. Hillary Clinton explicitly condemned her husband's policy when she ran for president in 2016.

Even more recently, Democratic politicians expressed strong reservations about the effects of uncontrolled immigration on the US labour force, sovereignty, and shared identity. In 2006, Senator Barack Obama explained,

'Native-born Americans suspect that it is they, and not the immigrant, who are being forced to adapt. In this way, the immigration debate comes to signify not a loss of jobs but a loss of sovereignty, just one more example that America seems unable to control its own destiny... And if I'm honest with myself, I must admit that I'm not entirely immune to such nativist sentiments. When I see Mexican flags waved at pro-immigration demonstrations, I sometimes feel a flush of patriotic resentment. When I'm forced to use a translator to communicate with the guy fixing my car, I feel a certain frustration... We have a right and duty to protect our borders. We can insist to those already here that with citizenship come obligations - to a common language, common loyalties, a common purpose, a common destiny.' 
When Obama ran for president in 2008, the Democratic Party took a strong line against illegal immigration. The 2008 Democratic platform condemned: 'We cannot continue to allow people to enter the United States undetected, undocumented, and unchecked. The American people are a welcoming and generous people, but those who enter our country's borders illegally, and those who employ them, disrespect the rule of the law. We need to secure our borders, and support additional personnel, infrastructure, and technology on the border and at our ports of entry'. The platform explicitly emphasised the impact of immigration on the labour market, a key concern of previous Democratic presidents.

The 2016 Democratic platform, however, took a different approach. Rather than condemn illegal immigration, it proposed support for those 'living in the shadows' and promised, 'We will invest in culturally-appropriate immigrant integration services, expand access to English language education, and promote naturalization to help the millions of people who are eligible for citizenship take that last step'.

The 2016 platform went further than previous Democratic platforms by offering guaranteed social services to illegal immigrants. The platform vowed to open access to the Affordable Care Act to 'all Americans - regardless of immigration status'. This would be a change to the law passed by the Democratic Congress in 2010, which barred illegal immigrants from healthcare subsidies under the ACA.

In the age of Trump, Democratic politicians have become critical about the enforcement of existing American immigration law. They strongly criticise President Trump for using ICE (Immigration and Customs Enforcement) agents to deport illegal immigrants. Some Democratic politicians have even called for the abolition of ICE altogether.

As a matter of electoral calculus, the polling on this issue presents a mixed picture. On the one hand, a majority of voters (52\%) opposed Trump's policy of separating migrant children from their families. On the other, only $19 \%$ of respondents in the same YouGov poll supported the Democrats' proposal of releasing illegal immigrants without charge. While three-quarters of Americans think that immigration is a 'good thing' for the country, the same Gallup polls do not show support for higher levels of immigration. In 2018, 68\% of Americans supported maintaining or decreasing the current levels of immigration to the United States.

\section{Electoral Implications}

In 1996, when Bill Clinton signed the Illegal Immigrant Reform Act, he won a plurality (44\%) of white voters without university degrees. Twenty years later, his wife Hillary Clinton won only 29\% support from this group. Democratic strategists have argued that the party should be willing to give up this group, in favour of targeting ethnic minority voters, who are presumed to be much more supportive of relaxed immigration policies. But, I would argue that this strategy is wrongly premised on two grounds. First, it underestimates the critical size of the white, working-class electorate. A multi-racial coalition of working-class voters is key to Democratic victory. Second, it wrongly assumes that minority voters are unquestioningly supportive of unrestrictive immigration policies.

A strategy which cedes white, working-class voters to the opposition is extremely precarious. Sixtyfour percent of white Americans over the age of 25 do not hold an undergraduate degree. Non-college educated whites (the statistical category most often used as a proxy for the white working-class), therefore, make up 39\% of the overall US population. A strategy which abandons the white workingclass to Republicans writes off nearly $40 \%$ of the US population.

Moreover, the institutional structures of American federalism provide areas with less diverse populations greater say in the American policy-making process. The US Constitution affords each state two votes in the US Senate, regardless of population differences. The consequence is that states which lack large, ethnically diverse populations also have the most power, proportionally, in deciding crucial national-level policy through the Senate and electing the President of the United States through the electoral college. Two-thirds of Latinos live in the five most populous states, greatly diminishing their voting power. 
Furthermore, Latinos are a much smaller proportion of the voting electorate than many commentators assume. This is because a much lower proportion of Latinos are US citizens than other groups, especially African Americans and whites. Even Latino US citizens tend to vote at much lower rates than other groups, often lagging behind black and white voters by as much as twenty percentage points.

In 2016, Latinos made up about $17.1 \%$ of the US population, compared to African Americans' $12.6 \%$. Yet, African Americans made up about $12 \%$ of voters, while Latinos made up only $11 \%$. More African Americans cast ballots than Latinos did, in spite of there being over 14 million more Latinos living in the United States than African Americans.

Table 1. Population versus Voter Demographic Comparison (2016)

\begin{tabular}{|c|c|c|c|c|c|}
\hline & $\begin{array}{c}\text { Proportion of } \\
\text { US } \\
\text { population }\end{array}$ & $\begin{array}{c}\text { Total } \\
\text { Population }\end{array}$ & $\begin{array}{c}\text { Proportion of } \\
\text { 2016 voters }\end{array}$ & $\begin{array}{c}\text { Total } \\
\text { Voters }\end{array}$ & $\begin{array}{c}\text { Population/ } \\
\text { Voter } \\
\text { Difference }\end{array}$ \\
\hline Whites & $61 \%$ & $198,077,165$ & $71 \%$ & $97,359,094$ & +10 \\
\hline Latinos & $18 \%$ & $57,516,697$ & $11 \%$ & $15,083,803$ & -7 \\
\hline Blacks & $13 \%$ & $42,975,959$ & $12 \%$ & $16,455,058$ & -1 \\
\hline Other & $8 \%$ & $24,557,691$ & $6 \%$ & $8,227,529$ & -2 \\
\hline TOTAL & $100 \%$ & $323,127,513$ & $100 \%$ & $137,125,484$ & \\
\hline
\end{tabular}

Sources: US Census Bureau (Population Estimates, 2016), CNN National Exit Poll (2016)

Additionally, the assumption that minority voters favour open immigration policies is excessively crude. Traditionally, African American voters were suspicious of attempts to encourage cheap migrant labour, being in an economic strata most directly vulnerable to low-skilled labour competition (Nteta 2014). Helen Morrow (2011)'s ethnographic study of low-skilled workers in the Deep South highlighted tensions between US-born African American labourers and immigrant Central American workers. Barack Obama himself identified black voters' concerns about illegal immigration:

'There's no denying that many blacks share the same anxieties as many whites about the wave of illegal immigration flooding our Southern border - a sense that what's happening now is fundamentally different from what has gone on before. Not all these fears are irrational. The number of immigrants added to the labor force every year is of a magnitude not seen in this country for over a century for over a century. If this huge influx of mostly low-skill workers provides some benefits to the country as a whole it also threatens to depress further the wages of blue-collar Americans and put strains on an already overburdened safety net'

Even Latino voters might not be as supportive of open immigration policies as much as Democratic strategists assume. In 2016, Latino voters voted in greater proportions for Donald Trump than they did for Mitt Romney. Latino voters, who are already US citizens, are less immediately impacted by Democrats' efforts to provide legal status to illegal immigrants. These citizens might have different views about immigration than non-citizen Latinos. Indeed, Latinos who were born in the United States or became naturalised US citizens might feel negative pressure in the workforce and in public services from non-citizen Latinos.

There is some evidence to suggest that Latino voters were not repelled by Donald Trump's harsh antiimmigrant rhetoric. Trump's performance among Latino voters was in line with other Republican candidates and even represented a slight improvement from Mitt Romney in 2012. In 2012, Barack Obama led Mitt Romney by 44 percentage points. In 2016, Trump narrowed the gap by 6 percentage points. While Democrats dominated the Hispanic vote in 2016 as they have done in recent elections, Trump's support among Latinos (28\%) was well within the norm for Republican candidates since 1992. Most Republican candidates win between a fifth and a third of the Latino vote, with George W Bush's performance in 2004 being an exception. 
Figure 1. Latino support for Republican nominee, 1992-2016

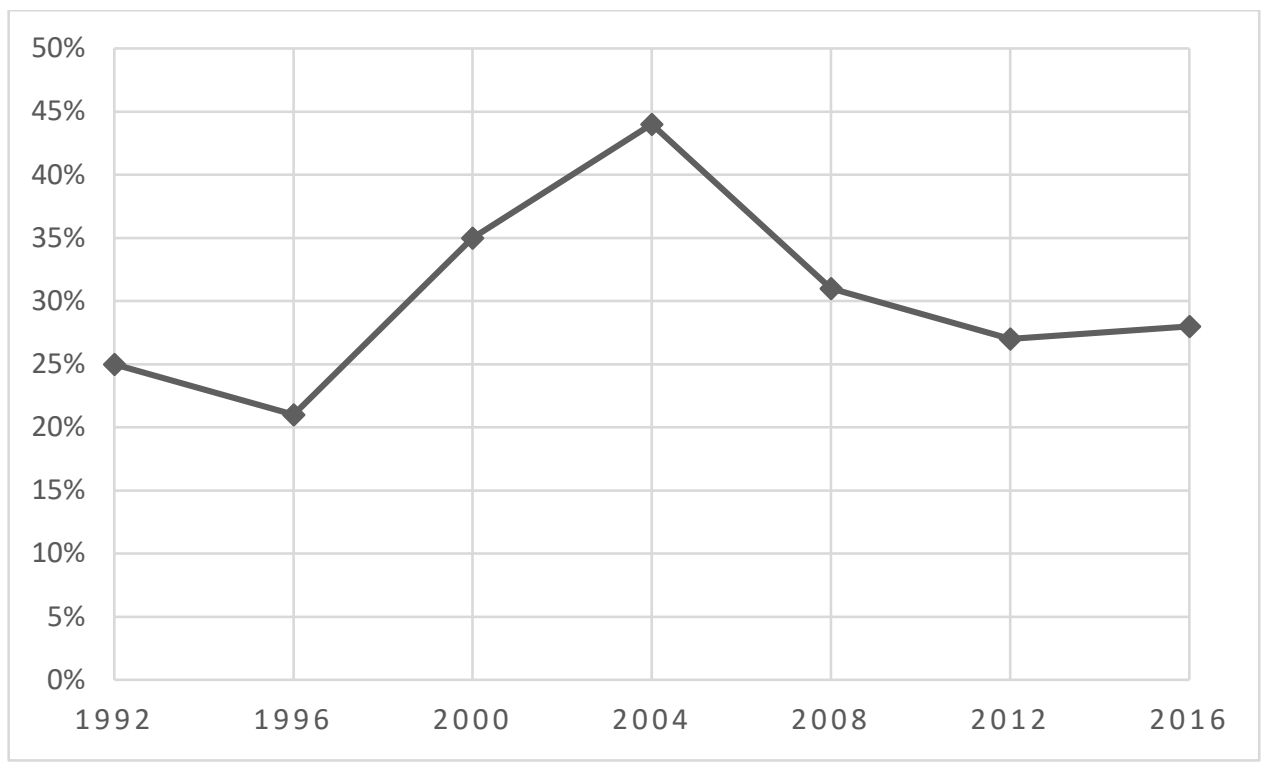

Source: National Exit Polls (1992-2016)

Some commentators have criticised the exit poll, claiming that its methods were flawed. However, using careful ecological analysis of official voting returns paired with demographic data from the US Census Bureau, I identify a similar trend from other sources. Aware of the dangers of the ecological fallacy, I look at counties which are almost entirely Hispanic (85.2-97.2\% of the population). In these counties, nearly all of the voters will be Hispanic. In the 14 most heavily Latino counties in the United States (at least 85\% Latino), Donald Trump improved on Mitt Romney's 2012 performance by an average of 2.5 percentage points. In the most heavily Latino county in the United States -- Starr County, Texas (97.2\% Latino) -- Trump outperformed Mitt Romney by 6.0 percentage points.

Table 2. Support for Republican nominee in most heavily Latino counties in the USA, 2012-16

\begin{tabular}{|c|c|c|c|c|}
\hline County (all Texas) & $\begin{array}{l}\text { Romney } \\
2012(\%)\end{array}$ & $\underset{2016(\%)}{\text { Trump }}$ & 2012-2016 change & $\begin{array}{c}\text { Latino Population } \\
(\%)\end{array}$ \\
\hline Starr County & 13.0 & 19.0 & +6.0 & 97.2 \\
\hline Webb County & 22.6 & 22.8 & +0.2 & 95.1 \\
\hline Maverick County & 20.6 & 20.7 & +0.2 & 95.1 \\
\hline Jim Hogg County & 21.4 & 20.3 & -1.1 & 92.7 \\
\hline Zavala County & 15.7 & 20.4 & +4.7 & 91.9 \\
\hline Zapata County & 28.1 & 32.8 & +4.7 & 90.8 \\
\hline Hidalgo County & 28.6 & 28.1 & -0.5 & 90.0 \\
\hline Brooks County & 21.1 & 23.6 & +2.5 & 90.0 \\
\hline Duval County & 22.6 & 31.6 & +9.1 & 88.1 \\
\hline Cameron County & 33.9 & 32.1 & -1.9 & 87.1 \\
\hline Willacy County & 28.0 & 30.3 & +2.4 & 86.9 \\
\hline Dimmit County & 26.1 & 30.2 & +4.1 & 85.2 \\
\hline AVERAGE: & 23.5 & 26.0 & +2.5 & 90.8 \\
\hline
\end{tabular}

Among Latino voters, both Trump and Romney lost to their Democratic opponent, but what these results suggest is that the Democrats did not gain any additional advantage among Latino voters for adopting a more liberal position (and, especially, tone) on immigration law in 2016. In contrast, some white 
voters and, plausibly, some African American voters were likely repelled by the Democrats' embrace of a more liberal immigration policies.

\section{Conclusion}

Immigration policy in the United States has undergone a process of polarisation over the past two decades. While Republicans have become much more supportive of restrictive immigration policies, Democrats now favour much more liberal policies than before. At times, the Democrats' rhetoric is hard to distinguish, especially for swing voters, from a belief in open borders. Donald Trump has capitalised on this confusion and pushed the Democrats to a position which twenty years ago they would not have held. Trump's sentiment, 'If you don't have borders, you don't have a country', not only resonates with large audiences of American voters but it is also an echo of the very same rhetoric used by Democratic politicians until recently. 